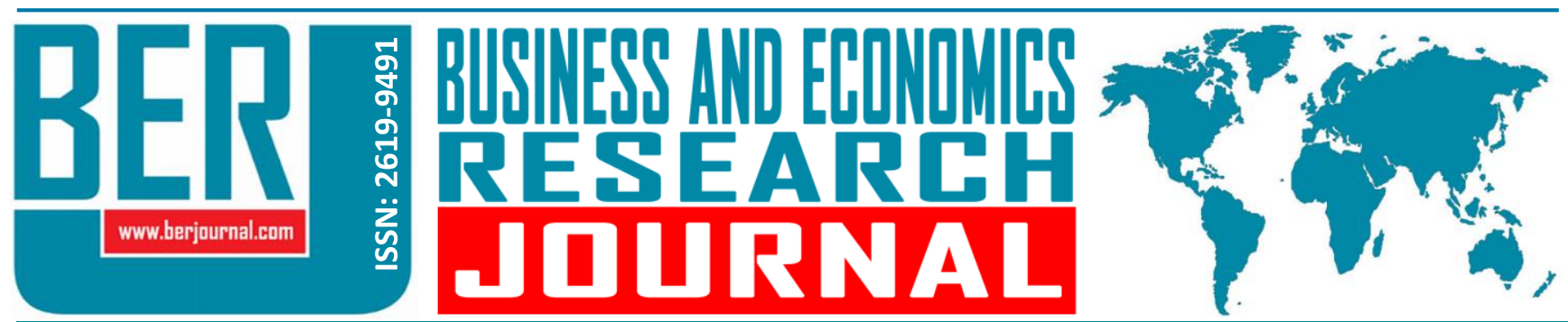

Business and Economics Research Journal Vol. 11, No. 4, 2020, pp. 953-968 doi: 10.20409/berj.2020.292

\title{
Hisse Senedi Fiyatlarının Para Politikasındaki Rolü: OECD Ülkeleri Örneği
}

\author{
Gulcin Tapsin
}

Öz: Varlık fiyatlarında 2000'li yıllar boyunca hızlı büyümeye eşlik eden canlanma ve global mali kriz sonucunda ortaya çıkan daralma, varlık fiyatlarının makroekonomik dalgalanmalar ve dolayısıyla para politikası üzerinde oynayabileceği role olan ilginin artmasına neden olmuştur. ilgili literatürde, para politikasının varlık fiyatlarına verdiği cevabı analiz eden çalışmaların endüstrileşmiş ülkelerin politika kurallarına yoğunlaştığı görülmektedir. Bununla birlikte, dünyadaki son mali krizlerin birçoğu, uluslararası sermaye akımlarına açık, gelişmekte olan ekonomilerde meydana gelmiştir. Bu makalenin odak noktası, gelişmiş ve gelişmekte olan ülkeler ayrımında para politikasının hisse senedi fiyat hareketlerine tepkisini analiz etmektir. Çalışma kapsamında, hisse senedi fiyat değişimlerinin ve piyasa kapitalizasyonu ile etkileşiminin kısa vadeli faiz oranları üzerindeki etkisi, OECD ülkeleri çerçevesinde, 2000-2019 yılları için Sistem-GMM yöntemi kullanılarak araştırılmıştır. Sonuçlar, piyasa kapitalizasyonunun yüksek olduğu gelişmiş ülkelerde, hisse senedi fiyatlarının kısa vadeli faiz oranı üzerindeki etkisinin, piyasa kapitalizasyonunun göreceli düşük olduğu gelişmekte olan ülkelerde, hisse senedi fiyatlarının kısa vadeli faiz oranı üzerindeki etkisinden yüksek olduğunu ortaya koymuştur. Çalışma aynı zamanda, enflasyon açığının kısa vadeli faiz oranı üzerindeki etkisinin pozitif ve anlamlı olduğunu, işsizliğin ise kısa vadeli faiz oranı üzerinde negatif ve anlamlı bir etkiye sahip olduğunu göstermiştir.

\section{The Role of Share Prices on Monetary Policy: The Case of OECD Countries}

Abstract: The recovery in asset prices during 2000's accompanied by quick growth and the recession caused by global financial crisis increased the interest in asset prices' role on macroeconomic fluctuations and hence monetary policy. In the relevant literature, it is seen that the studies analyzing the response of the monetary policies to the asset prices focus mostly on policy rules of the industrialized countries. In addition, most of the financial crises throughout the world happened in the developing economies that were open to international capital flows. The main focus of this article is to analyze the response of monetary policy to share price movements for the purpose of differentiating the developed and developing countries. Within the scope of this study, the effect of share price changes, market capitalization and interaction on short-term interest rates was researched for OECD countries for the period of 2000-2019 by means of SystemGMM method. The results showed that the effect of share prices on short-term interest rates in the developed countries with high market capitalization was higher than the effect of those in the developing countries with asset lower market capitalization. The study also demonstrated that the effect of inflation deficit on short-term interest rate was positive and significant while unemployment had negative and significant effect on short-term interest rate.

Anahtar Sözcükler: Hisse Senedi Fiyatları, Para politikası, Enflasyon Açı̆̆ı, GMM Modeli

JEL: C22, E32, E52, E31, E01

$\begin{array}{ll}\text { Geliş } & : 08 \text { Mayıs } 2020 \\ \text { Düzeltme } & : 24 \text { Haziran } 2020 \\ \text { Kabul } & : 28 \text { Eylül } 2020 \\ \text { Tür } & : \text { Araştırma }\end{array}$

Keywords: Share Prices, Monetary Policy, Inflation Deficit, GMM Model

JEL: C22, E32, E52, E31, E01

Received : 08 May 2020

Revised : 24 June 2020

Accepted : 28 September 2020

Type : Research 


\section{Giriş}

1980'lerde enflasyonu kontrol altına almayı hedefleyen başta Amerika Birleşik Devletleri (ABD), Japonya, İngiltere, Hollanda, İsveç ve Finlandiya gibi gelişmiş ülkelerde ve ardından 1990'larda Doğu Asya ve Latin Amerika'da hisse senedi ve gayrimenkul fiyatlarındaki ani yükseliş ve düşüşlerin, makroekonomik istikrarsızlık üzerindeki etkilerine yönelik ilgi artmıştır. 2008-2009 global finans krizi, mevcut makroekonomik yapılardaki bazı dezavantajlara atıf yaparak bu konuyu gündeme taşımış, finansal piyasalarda, davranışsal ve spekülatif faktörlerin etkisinin yanısıra merkez bankalarının finansal baloncuklara vereceği cevaba ilişkin konular da tartışma alanı bulmuştur. Illk olarak, Greenspan (1996), "Demokratik Toplumda Merkez Bankacılığının Mücadelesi" başıklı konuşmasında, "irrasyonel taşkınlığın"' hisse senedi fiyatlarını aşırı derecede tırmandırarak yaratttığı balonun, Japonya'da olduğu gibi uzun süreli daralmalar şeklinde makroekonomik sonuçları beraberinde getirebileceğini belirtmiştir. Bununla birlikte, bir finansal varlık balonuna, reel ekonomi ve fiyat istikrarına zarar verme tehdidinde bulunmuyorsa, merkez bankaları tarafından müdahale edilmemesi gerektiği görüşünü ileri sürmüştür. Ancak, varlık piyasaları ile ekonomi arasındaki etkileşimlere karşılık merkez bankalarının kayıtsız kalmaması gerektiğini belirtmiş, genel olarak bilançolarda ve özellikle varlık fiyatlarındaki değişimlerin değerlendirilmesini para politikasının ayrılmaz bir parçası olarak tanımlamıştır.

Bu kapsamda, hisse senedi fiyatlarının enflasyon baskılarını artırabilecek güçlü bir ekonomik etki yaratması durumunda, enflasyon odaklı bir merkez bankasının, kısa vadeli faiz oranını artırması beklenen bir durum olabilir. Hisse senedi fiyat hareketlerinin, hanehalkı tüketim harcamaları ve firmaların yatırım harcamalarını doğrudan etkilemesi halinde enflasyon üzerindeki olası etkisi merkez bankaları tarafından dikkate alınacak ve faiz oranı buna bağlı olarak cevap verecektir (Fuhrer ve Tootell, 2008). Hisse senedi fiyatları parasal aktarım mekanizmasının varlık kanalının bir alt unsuru olarak toplam harcamalar üzerindeki etkisi ölçüsünde optimum para politikası açısından önemlidir. Teoride, hisse senedi fiyatlarındaki artış, bu varlıkları ellerinde tutan hanehalklarının servetlerinin ve buna bağlı olarak tüketim harcamalarının artmasına neden olmaktadır. Modigliani tarafından geliştirilen yaşam boyu gelir hipotezine göre, hanehalklarının tüketim harcamaları yaşam boyu elde edecekleri gelire bağlıdır. Hipotez, hanehalkının sahip olduğu finansal servetin büyük bir kısmının hisse senetlerinden oluştuğunu varsayar. Hisse senedi fiyatlarındaki artış, finansal servetin değerini ve hanehalklarının yaşam boyu gelir ve tüketimlerini arttırmaktadır (TCMB, 2013). Hisse senedi fiyatları işletmelerin sabit yatırımları üzerinde de belirleyicidir. Tobin'in $Q$ modeli, sermayenin kullanım maliyeti ve finansal hızlandırıcılar (kredi verenlerin ahlaki tehlikelere ilişkin endişelerini azaltan ve dolayısıyla bir patlama sırasında dış mali kısıtlamalar konusundaki çekincelerini bertaraf eden kurumsal net değer seviyesi) kanalıyla işlemektedir. Hisse senedi fiyatlarının yatırım etkisi belirsizlik ve onun firma güvenirliği üzerindeki etkisi yoluyla ortaya çıkmaktadır (Davis, 2010).

Reinhart (2005), ABD'de reel GSYiH ve bazı bileşenlerine ilişkin üç aylık verileri kullanarak hisse senedi fiyatlarının harcamaları önemli ölçüde etkilediğini göstermiştir. Hisse senedi fiyatlarının en büyük etkisinin yatırımlar üzerinde görüldüğünü ve artan hisse senedi fiyatlarının özellikle son 10 yıllık süreçte sermayenin genişlemesine katkıda bulunduğuna işaret etmiştir. Yüksek servet kaynaklı artışların sonucu olarak toplam talep arttığında, enflasyon hedeflemesi yapan merkez bankaları, Taylor (1993) tarafından geliştirilen model kapsamında kısa vadeli faiz oranlarını sıkılaştırarak hisse senedi fiyatlarındaki artışı dizginlemek için kademeli (faiz düzleştirme) bir yaklaşım takip etmektedir.

Merkez bankasının değişen ekonomik koşullara genel olarak nasıl tepki verdiğini göstermek için çıktı ve enflasyon açığını kısa vadeli faiz oranının tarihsel davranışıyla ilişkilendiren Taylor (1993) kuralı ve varyasyonları merkez bankaları açısından önemli bir rehber olarak kabul edilmektedir. Taylor kuralı, bir merkez bankasının ekonomiyi nasıl dengede tutmaya çalıştığını açıklar. Taylor (1993) kuralına göre, kısa vadeli faiz oranları enflasyonu kontrol etmek için yükselirken ekonomi durgunlaştığında çıktı ve istihdamı canlandırmak için düşer. Orijinal Taylor kuralı, federal fon oranı değişikliklerinin, enflasyon ve çıktıdaki geçmiş hareketleri yansıtacak şekilde yapılmasını gerekli gördüğü için geriye dönüktür. Son yıllarda, araştırmalar Fed'in beklenen enflasyon ve çıktıya da yanıt verdiğini, dolayısıyla Taylor kuralının daha yeni, ileriye dönük versiyonlarının ortaya çıktığını göstermiştir. Clarida'da tartışıldığı gibi tepki fonksiyonları, kısmi ayarlamalara, faiz oranındaki dalgalanmaların finansal piyasalar üzerindeki yıkıcı etkilerini önlemek amacıyla faiz 
düzleştirmesine veya gecikmeli bir bağımlı değişkenin dahil edilmesine izin vermek için geliştirilmiş Taylor politika kuralları biçimini almıştır. Clarida, Gali ve Gertler (1998, 1999, 2000)'in geliştirdikleri tepki fonksiyonları, para politikasının etkilerindeki gecikmeleri göz önüne almakta ve tepki fonksiyonlarında enflasyon beklentilerine ve çıktı açığına cevap veren optimal federal fon oranını tanımlamaktadır. Benzer şekilde Koenig (2004)'de tepki fonksiyonunda ileriye dönük yaklaşımı kullanırken, Murray, NikolskoRzhevskyy ve Papell (2008), geriye dönük yaklaşımı benimsemiştir (Fernandez ve Nikolsko-Rzhevskyy, 2007).

Taylor (1993) kuralı ve versiyonlarını takiben 2000'li yıllar boyunca enflasyon hedeflemesi yapan merkez bankalarının faiz oranları ile varlık fiyat hareketlerini ilişkilendirdikleri çalışmalar, para otoritelerinin varlık fiyatlarındaki balonlara doğrudan müdahale etmekle (rüzgara karşı durma/lean), balon patladıktan sonra (sonradan temizleme/mop up after) yayılım etkilerini bertaraf etmek adına tepki göstermek gibi iki farklı düşünce akımı etrafında temellenmiştir. 2008 global finans krizi öncesinde literatürde hakim olan görüş reaktif (tepkisel) politikalar içeren "sonradan temizleme" stratejisi iken kriz sonrası dönemde proaktif (önleyici) politikalar içeren "rüzgara karşı durma" stratejisi yaygın kullanım alanı bulmuştur. Rüzgara karşı durma stratejisi, varlık balonlarının patlamadan önce faiz oranlarının yükseltilmesiyle proaktif bir şekilde önlenmesini gerekli kılar. Reaktif akımın temsilcileri, Bernanke ve Gertler (2001), Schwartz (2002) ve Greenspan (2007), merkez bankalarının hisse senedi fiyatlarını etkilemek için proaktif (önleyici) bir politika takip etmemesi gerektiğini savunmuştur. Hisse senedi fiyatları, piyasanın ileriye dönük kurumsal karlara ilişkin örtük değerlendirmesini içerdiği, servete katkıları ve göreli getiri üzerindeki etkileri ile harcamaları doğrudan etkilediği, para politikasının eşzamanlı bir sinyali oldukları ölçüde politika yapıcılar tarafından dikkate alınmalıdır (Chami, Cosimano ve Fullenskamp, 1999). Reaktif (sonradan temizleme) düşünce akımının savunucuları, yaklaşımlarını gerekçelendiren üç konuya işaret etmektedir. Birincisi, merkez bankalarının varılı fiyatlarındaki yanlış hizalamalarını tespit edemeyebileceğine yöneliktir. ìkincisi, para politikasının genellikle küt bir araç olarak görülmesine ilişkindir. Bu kapsamda, küçük bir faiz oranı artışı, hisse senedi fiyatlarındaki ani yükselişi daha da arttırabilir - patlamayı yavaşlatmak veya balonu delmek için gerekli faiz artışı ciddi bir durgunluğa yol açabilir. Üçüncüsü, aktif bir şekilde davranan para politikası güvenilirlik sorunlarına yol açabilir: asıl amacı enflasyonu istikrara kavuşturmak olan merkez bankaları, özellikle düşük enflasyon söz konusu olduğunda piyasaların parasal sıkılaştırılmasında sorun yaşayabilir ve bu nedenle kredibiliteleri riske girer şeklindedir (Knütter ve Wagner, 2012).

2008 global finans krizinden sonra hakim olan proaktif (rüzgara karşı durma) düşünce akımının temsilcileri, Smets (1997), Cecchetti, Genberg, Lipsky ve Wadhwani (2000), Cecchetti, Genberg ve Wadhwani (2002), Bordo ve Jeanne (2002), Borio ve White (2004) ve Roubini (2006)'ye göre ise, hisse senedi fiyatları genellikle kabarcıklara ve çökmelere maruz kalmaktadır. Bunların döngüsel etkileri güçlü olabilmekte ve finansal piyasaların istikrarını da etkileyebilmektedir. Merkez bankaları finansal istikrardan sorumlu oldukları için varlık fiyatlarını izlemeli ve balonların ortaya çıkmasını önlemeye çalışmalıdır (Grauwe, 2008). Proaktif (önleyici) stratejiyi savunan literatüre göre genel argümanlar şunlardır: birinci argüman, tanımlama (spesifikasyon) problemiyle (hisse senedi fiyatlarının uzun dönem tahmini) ilgilidir. Proaktif stratejinin savunucuları, para politikasının yürütülmesinde kullanılan çıktı açığı gibi diğer değişkenlerin de değerlendirilmesinin zor olduğunu savunmaktadır. İinci argüman, merkez bankası kısa vadede hedeflere ulaşmada başarısız olsa bile, balonun ortaya çıkış aşamasında uygulanan sıkı bir politikanın, balonun patlaması durumunda uygulanacak olan politikadan daha düşük makroekonomik maliyetlere yol açacağını ileri sürmektedir. Üçüncüsü ahlaki tehlikeye yöneliktir. Piyasa katılımcıları para politikasının patlayan bir balonun sonuçlarını telafi edeceğini bilirlerse, patlama döneminde bile yatırım yapmaya teşvik edilebileceklerini ileri sürer. Proaktif stratejinin savununcularının ileri sürdüğü diğer bir gerekçe, önleyici olarak hareket ettiği bilinen para politikasının sırasıyla kabarcıkların oluşmasını ve büyümesini önlemeye yardımcı olabileceğine yönelik bir değerlendirmedir. Nihai olarak bu düşünce akımı, merkez bankalarının, varlık fiyat balonları tarafından tehdit edilen finansal istikrarın sağlanmasından sorumlu olduğunu belirtmektedir (Knütter ve Wagner, 2012).

Merkez bankaları hisse senedi fiyatlarını para politikası formülasyonunda açıcça dikkate almayarak reaktif (sonradan temizleme) stratejisinin ileri sürdüğü sorunları ortadan kaldırsa bile, yine de sistemik riskle ilgili endişelerin ötesinde hisse senedi piyasalarını izlemek durumunda kalabileceği yönünde ortak bir görüş 
sözkonusudur. Nitekim proaktif stratejiyi savunan çalışmalar, optimal politika seçiminde, varlık balonlarının, kredi krizi olasılığı, irrasyonel taşkınlık, özel sektörün ileriye dönük davranış eğilimi, para politikasının gecikme süreleri gibi ekonomik belirleyicilerle olan karmaşık ilişkisini teknoloji şokları ve verimlilik artışından ayırdederek analiz edilmesi gerekliliğine işaret etmektedir. Bu çalışma, hisse senedi fiyatlarının, ekonomik faaliyeti ve enflasyonu tahmin etme kabiliyetini tartışarak merkez bankalarına, optimal politika seçiminde, hisse senedi fiyatlarına cevap vermeleri gerektiği yönünde bir öneride bulunmaktan ziyade, söz konusu varlık fiyatlarının merkez bankalarının politika uygulamasında halihazırda kullanılıp kullanılmadığını ortaya koymaktadır. Çalışma, hisse senedi fiyatlarının gelişmiş ve gelişmekte olan ülkeler temelinde para politikası üzerindeki olası etkilerini analiz ederek, konuyu çoğunlukla gelişmiş ülkeler perspektifinden ele alan mevcut literatüre katkı yapmayı amaçlamaktadır. Bu kapsamda, OECD ülkelerinden oluşan bir örneklemde 2000-2019 yılları için merkez bankalarının hisse senedi fiyat hareketlerine verdiği cevap Sistem GMM yöntemi kullanılarak analiz edilmiştir. Çalışmanın ikinci bölümünde, ilgili literatür taraması, üçüncü bölümünde, veri seti ve yöntem, dördüncü bölümünde ampirik model yer almaktadır. Beşinci bölümde ampirik analizden elde edilen sonuçlar yorumlanmıştır.

\section{Literatür}

Literatürde, global finans krizinden önce, reaktif (sonradan temizleme) stratejinin hakim görüş olduğu görülmektedir. Reaktif politikanın temsilcilerinden Bernanke ve Gertler (1999), yapışkan fiyatlarla dinamik Yeni Keynesyen bir model çerçevesinde, varlık fiyatlarını etkilemesi beklenen tüm temel verileri, diğer etkenlerden ayırmak suretiyle, varlık balonlarının oluşumunu ve para politikası üzerindeki etkilerini analiz etmişlerdir. Analiz neticesinde varlık balonlarındaki patlamanın piyasalarda keskin daralmaya neden olan makroekonomik riskleri ve talep daralmasını beraberinde getirdiğini göstermişlerdir. Varlık balonu patladıktan sonra ise, uygun koşul ve şartlarda uygun bir para politikasının uygulanmaması halinde ekonomik daralmanın daha da arttığını tespit etmişlerdir. Bununla birlikte, merkez bankalarının beklenen enflasyonda istikrar sağlamak için enflasyonist veya deflasyonist baskıların tahminine yardımcı olmaları haricinde varlık fiyatlarına cevap vermemesi gerektiği yönünde görüş bildirmişlerdir.

Bernanke ve Gertler (2001), geliştirdikleri optimal politika içeren simülasyonda, merkez bankasının nominal faiz oranını gelecek dönemin beklenen enflasyonu, hisse senedi piyasasının mevcut seviyesi ve çıktı açığıyla (esnek fiyatlar altında ve kredi sürtüşmesi olmaksızın fiili çıktı eksi çıktı olarak tanımlanmıştır) ilişkilendiren basit kuralları dikkate almışlardır. Faiz oranının beklenen enflasyona tepkisinin 1,01 ile 3 arasında, günlük hisse senedi fiyatlarına tepkisinin 0 ile 0,2 arasında ve çıktı açığına tepkisinin 0 ile 2 arasında değiştiğini tespit etmişlerdir. Simülasyonda sadece enflasyonu hedefleyen bir kurala, hisse senedi fiyat yanıtını eklemenin, çıktı açığının değişkenliğinde küçük bir azalmaya yol açtığını gözlemlemişlerdir. Bu etkiye yönelik geliştirdikleri yorum; hisse senedi fiyatlarındaki bir şokun (bir balondan veya teknolojiden) doğal reel faiz oranını geçici olarak değiştirebileceği ve sözkonusu değişikliğin ilke olarak tamamen optimal bir politika kuralıyla adapte edilmesi gerektiği şeklindedir. Bu nedenle hisse senedi fiyatlarına küçük bir ağılık koymanın, bazı durumlarda ve bazı boyutlarda yardımcı olabileceğini belirtmişlerdir. Bununla birlikte geliştirilen simülasyonlar, politika kuralının, çıktı açığına yanıt vermesine izin vermenin hisse senedi fiyatlarına yanıt vermenin faydasını ortadan kaldırdığını göstermiştir. Yazarlar, hisse senedi fiyatlarının temel bileşenini ölçmenin çıktı açığını ölçmekten daha zor olduğunu, enflasyon davranışının, çıktı açığının büyüklüğüne gerçek zamanlı bir gösterge sunduğunu, stok fiyatları tahminlerinin doğrulanmasını sağlayacak benzer bir göstergenin bulunmadığını ileri sürmüşlerdir. Bu nedenle, kayıp fonksiyondaki makul parametre değerleri için merkez bankasının varlık fiyatlarına cevap vermemesi gerektiği sonucuna varmışlardır.

Örneğin, hisse senedi fiyatlarının uzun dönemli denge seviyesinden biraz daha yüksek olduğu, buna karşıık reel oranların doğal dengesinde seyrettiği bir ekonomide, para politikasının durağan durum dengesi için doğru bir şekilde ayarlandığı söylenebilir. Bu noktada, hisse senedi fiyatlarının uzun dönem seviyesinin üzerinde seyrediyor olmasından dolayı para politikasının mevcut hisse senedi fiyatları seviyesi için çok gevşek olduğunu söylemek anlamlı olmayacaktır. Hisse senedi fiyatlarının uzun dönemli denge seviyesinin üzerine çıktığı bir düzeyden itibaren sürekli artış göstererek toplam talebi uyardığı koşullar, yakından takip edilmelidir (Reinhart, 2005). 
Reaktif bir politika duruşunu savunan diğer yazarlardan Gilchrist ve Saito (2006), finansal hızlandırıcılı Yeni Keynesyen bir model kullanarak varlık fiyat açığına yanıt vermenin, politika yapıcıların teknolojinin büyümesini doğru bir şekilde tanımlayabilmeleri durumunda en büyük kazancı sağladığını göstermişlerdir. Goodfriend (2003), faiz oranları ile hisse senedi fiyatları arasında pozitif bir korelasyon olmadığını 1980'lerin sonunda Japonya'da ve 1990 'ların sonunda ABD'de para politikasının doğrudan varlık fiyatlarına tepki göstererek iyileştirilemediğini referans göstererek açıklamış, para politikasının varlık fiyatlarına doğrudan yanıt vermemesi gerektiğini, hatta para politikasının zıt yönde hareket etmesinin gerektiği durumların da sözkonusu olabileceğini vurgulamıştır. Nitekim, Geske ve Roll (1983), iktisat teorisinin aksine, hisse senedi getirilerinin hem beklenen hem de beklenmeyen enflasyonla, negatif ilişkili olduğunu göstermişlerdir. Bununla birlikte, hisse senedi getirilerinin balonlara maruz kalmasının bir dizi mali ve parasal tepki zincirini tetikleyeceğini ileri sürerek ilişkinin yönü ne olursa olsun konunun para politikası açısından önemine vurgu yapmışlardır. Geske ve Roll (1983)'a göre, tesadüfi negatif (pozitif) bir reel şok, daha yüksek (düşük) işsizlik ve düşük (yüksek) kurumsal kazançlara işaret eden hisse senedi getirilerini etkileyecektir. Bu durum, daha düşük (daha yüksek) kişisel ve kurumsal vergi gelirlerine yol açar. Kamu harcamaları gelirlerdeki değişime uyum sağlamak için değiştirilmediğinde, hazinenin açığı artar (azalır). Hazine, kamudan borçlanmayı artırarak (azaltarak) bu duruma yanıt verir. Merkez bankaları, hazine borcundaki değişikliklerin bir kısmını satın alır ve sonunda parasal tabanın büyüme oranını artırarak (daraltarak) bunu öder. Akılcı yatırımcılar, borsa tarafından gönderilmiş rastgele bir reel şokun bu mali ve parasal tepki zincirini tetikleyeceğini fark edeceklerdir. Böylece, kısa vadeli menkul kıymetlerin fiyatlarını hisse senedi getiri sinyaliyle eş zamanlı olarak değiştirirler.

Teorik temelden gelen mesaj, hisse senedi fiyatlarının, sistemik risk, harcama ve güven üzerindeki zincirleme etkiler ve ardından ani düşme riski nedeniyle daralma dönemlerinde sorun olabileceği yönündedir. Prensip olarak, merkez bankası, bir varlık balonunun şişmesini, hisse senedi fiyatları ile ilgili kaynakların yanlış yerleştirildiğini ima eden bir sinyal olarak algıladığı veya varlık balonunun patlamasının sistemik riskleri tehdit ettiği ya da makroekonomik yayılımların, iskonto penceresi de dahil olmak üzere para politikası araçları yoluyla önlenemeyeceği yönünde bir endişe duyduğu noktada, hisse senedi fiyatlarını gözönüne almalıdır. Yine de teorik temel, bu tür yaklaşımların dikkatli bir şekilde ele alınması gerektiğine işaret etmektedir. Hisse senedi fiyatları gerçekten para politikasının duruşuna işaret ederken, bunlara mekanik bir şekilde yanıt vermek, oynaklıklarını artırabilmekte ve aşırı derecede istikrarsızlaştırabilmektedir. Örneğin, bazı ekonomik modeller, hisse senedi fiyatları seviyesine yanıt vermenin, haberlerin hisse senedi fiyatları üzerindeki net etkisini artırdığını göstermektedir (Reinhart, 2005). Vasilenko (2017), bilgi politikasının etkinliğinin olmadığı bir ortamda varlık fiyatı kabarcıklarını, sadece faiz oranını yükseltmek suretiyle sıkıştırmanın, sosyal refah ve finansal istikrar üzerinde olumsuz sonuçlara yol açtığını savunmuştur.

Benzer şekilde, Svensson (2004), Avrupa Merkez Bankası'nın varlık fiyatı hareketlerini ve potansiyel varlık fiyatı balonlarını, yalnızca bunların para politikasına yön vermesi gereken enflasyon ve çıktı açığı tahminleri üzerinde bir etkiye sahip oldukları kabul edildiği ölçüde hesaba katması gerektiğini belirtmiştir. Varlık fiyatları, enflasyon ve çıktı açığına ek olarak ayrı bir hedef değişken olarak belirlenmemelidir. Bir varlık fiyatı hareket ettiğinde, ilk adım, temelde yatan şoku ve doğasını ortaya çıkararak şokun geçici mi yoksa kalıcı mı olduğunu değerlendirmektir. İkinci adım, şokun ve doğasının enflasyon ve çıktı açığı tahminleri üzerindeki etkisini değerlendirmektir. Etki, örneğin, şokun niteliğine ve sürekliliğine bağlı olacaktır. Ayrıca, çıktı açığı tahmini üzerindeki etkinin tahmin edilmesi, hem çıktı hem de potansiyel çıktı tahminleri üzerindeki etkinin değerlendirilmesini gerektirir. Potansiyel çıktı, tahminlenmesi güç olan bir kavramdır. Üçüncü adım, enflasyon ve çıktı açığı tahminlerindeki kayma göz önüne alındığında, enflasyon ve çıktı açığı tahminlerinin iyi görünmesi için faiz planında hangi revizyonun yapılması gerektiğine karar vermektir. Dördüncü ve son adım, yeni enstrüman faizini duyurmak, uygulamak ve yukarıdaki üç adımın analizini ve sonucunu gözlemcilere ve genel halka açıklamaktır. Greenspan (2004) da enflasyon, reel üretim, hisse senedi fiyatları ve döviz kurlarının izlediği yolların önceden tahmin edilmesindeki belirsizlik konusunda Svensson (2004) ile benzer görüşleri paylaşmaktadır. Belirsizlik ortamında, büyük ölçüde öngörülemeyen sonuçları olan sert eylemlerle, varsayılan bir balonu sınırlandırmaya çalışmak yerine, bir balon ortaya çıktığında olumsuz etkileri hafifletmek ve bir sonraki genişlemeye geçişi kolaylaştırmak için politikalara odaklanmayı önermiştir. 
Posen (2006)'e göre, merkez bankaları varlık fiyat balonlarını patlatmaya çalışmakla uğraşmamalıdır. Kabarcıklara genellikle irrasyonel coşkunluk, teknolojik sıçramalar ve finansal deregülasyonun neden olduğunu, parasal koşullar ile balonların yükselişi arasındaki bağlantının oldukça zayıf olduğunu ve bir merkez bankasının faiz oranlarını yükselterek intiyaç duyulan şeyi başarmasının olası olmadığını belirtmiştir. Patlayan balonların maliyeti büyük ölçüde ekonominin finansal sisteminin yapısına ve kırılganlığına bağlıdır. Düzgün bir şekilde denetlenen ve düzenlenen ve likit piyasalara sahip bir finansal sistemin genişleyen ve patlayan bir balondan gerçek anlamda fazla zarar görmeyeceğini belirtmiştir. Finansal sistemin kırılgan veya uygunsuz bir şekilde denetlenmesinin, reel ekonomik açıdan daha da maliyetli olacağını ileri sürmüştür. Parasal sıkılaştırmanın balonları patlatmak veya finansal kıılganlığa yanıt vermek için etkisinin olmamasını ve resesyonları tetiklemenin balonları söndürmekten çok daha fazla maliyetli olmasını modern finansal sistemlerin ve balonların karakteristik yapısal özellikleri olarak tanımlamıştır.

Blinder ve Reis (2005), merkez bankalarının oluşan varlık balonunu patlatıp patlatmaması gerektiği sorusunu incelemiş ve bu kapsamda Fed'in Greenspan yönetimindeki politikasını analiz etmişlerdir. Greenspan tarafından yürütülen ve "sonradan temizleme" stratejisi olarak adlandırılan politikayı savunmuşlardır. Schwartz (2002), merkez bankalarının, düşük varlık fiyatları endişesi nedeniyle parasal genişlemeye girmemesi gerektiğini belirtmiştir. íkinci uyarısı, varlık fiyat balonlarını patlatmak için doğrudan para politikası kullanılmaması gerektiğine yöneliktir. Varlık fiyatlarındaki patlamalar balon gibi göründüğünde piyasanın kendini düzeltmesine izin verilmesi gerektiğine vurgu yapmışır. Yazara göre, Federal Rezerv varlık fiyatlarının doğru seviyesinin belirleyicisi değildir. Olumlu kazanç büyüme tahminlerinin yokluğunda hisse senedi piyasası fiyatlarının yükselmeyeceğini, sözkonusu kazanç büyüme tahminleri azalmadıkça çökmeyeceklerini belirterek rasyonel piyasa teorisini benimsemiştir. Rasyonel piyasa teorisinin destekçilerinden Greenspan (2002), hisse senedi fiyatlarının federal fon oranının artırılmasından sonra birkaç kez arttığına atıf yaparak artan bir şekilde uygulanan sıkı bir para politikasının, toplam talebi azaltacağını ve dolayısıyla hisse senedi fiyatlarını kademeli olarak belirleyebileceğini gösteren makro modellere karşı çıkmışır. Greenspan'in “tarih, baloncukların kademeli veya doğrusal olarak değil, aniden, tahmin edilemez ve çoğu zaman şiddetli bir şekilde tanımlanma eğiliminde olduğunu gösterir" şeklindeki ifadesi, onu, benimsemiş olduğu rasyonel piyasa teorisi ile çelişkili olarak, spekülatif piyasa teorisi savunucusu Galbraith ile kabul edilmemiş bir anlaşmaya sokmuştur (Raines, Mcleod ve Leathers, 2007).

Literatürde, global finans krizinden sonraki dönemde proaktif (rüzgara karşı durma) stratejiyi benimseyen çalışmalar yaygınlaşmıştır. Proaktif stratejinin savunucularından Smets (1997), varlık fiyatlarının para politikası oluşumunda rol oynamasının en az iki nedeni olduğunu belirtmiştir. Birincisi, varlık fiyatlarının, gelecekteki getiri beklentilerinden dolayısıyla gelecekteki ekonomik aktivite, enflasyon ve para politikası beklentilerinden güçlü bir şekilde etkilenmesine ilişkindir. Bu nedenle, toplam talep üzerindeki etkileri sınırlı olsa bile, mevcut ve gelecekteki ekonomik koşullar hakkında yararlı bilgiler içerebilmektedir. Dolayısıyla, optimal para politikasının varlık fiyatlarına vereceği cevap bu fiyatlarda yer alan bilgilere bağlı olacaktır. ikinci neden, varlık-fiyatındaki büyük ve kalıcı yanlış hizalamaların yaygın finansal istikrarsızlığa yol açabileceği ölçüde merkez bankasının önemli bir hedefi olması gerektiğine yöneliktir.

Kent ve Lowe (1997), bir varlık-fiyat balonu ortaya çıktığında, beklenen enflasyon (geçici olarak) hedefin altında olsa bile balonun çok büyümeden önce çökmesini sağlamak için para politikasının sıkılaştırılması gereken durumlar olabileceğini göstermişlerdir. Böyle bir politikayı daha büyük bir varlık fiyatı balonunun uzun vadeli etkilerinden ve nihai çöküşünden kaçınmaya yardımcı olabileceği için optimal olarak nitelendirmişlerdir. Yazarlar, söz konusu politikanın uygulanma gerekçelerini üç temel unsura dayandırmıştır. Birincisi, daha sıkı bir para politikasının balonun patlama olasılığını artıracağına yöneliktir. İkincisi, balon patladığında bir süre tekrar ortaya çıkmayacağı beklentisidir. Üçüncüsü, para otoritesinin yüksek enflasyon sonuçlarının ortaya çıkma olasılı̆̆ından kaçınmak istemesidir. İyi bir mali düzenleme ve denetlemenin, varlık fiyatı balonlarındaki çöküşlerin maliyetlerini önemli ölçüde azaltabileceğini belirtmişlerdir. Bu düzenlemelerin, para politikasının varlık fiyatı balonlarına tepki verme ihtiyacını ortadan kaldırmasa da azaltması, beklenen enflasyonun hedefe daha yakın olmasına ve çıktının potansiyel üretime daha yakın olmasına izin vermesi gerektiğini ifade etmişlerdir. Düşük enflasyon ortamında varlık fiyatı balonlarının daha az olası olduğunu, ancak meydana gelirlerse daha maliyetli olabileceğini ileri sürmüşlerdir. Bu sonucu, varlık 
fiyatı gelişmelerinin, mal ve hizmet fiyat enflasyonu hedefte veya hedefe yakın olsa bile, merkez bankaları tarafından dikkatle incelenmesi gerektiği şeklinde yorumlamışlardır.

Cecchetti vd. (2000), faiz oranının enflasyona, hisse senedi fiyatlarına ve çıktı açı̆̆ına tepkilerinin büyüklüğünün dışsal olarak belirlendiği bir politika kuralını araştırmışlardır. Politika yapıcıların sırasıyla çıktı ve enflasyon değişkenliğinin ağırlıklı ortalamasını en aza indirmeye çalıştıkları bir politika kuralının her zaman hisse senedi fiyatlarına tepki verdiği sonucuna ulaşmışlardır. Ayrıca, hisse senedi fiyatlarına tepki verme yeteneğinin para politikasının hedefe yönelik performansını önemli ölçüde artırdığını göstermişlerdir. Kuralın hisse senedi fiyatından ziyade borsa balonuna tepki içermesi halinde de sonuçların niteliksel olarak değişmediğini not etmişlerdir. Politika yapıcıların, varlık fiyatlarının spekülatif bileşenlerini temel nedenlerden ayırabilmesi durumunda, bu yeni bilginin politika yapıcıların zararı azaltmasına izin vereceğini göstermişlerdir. Yazarlar, yüksek verimlilik artışının yol açtığı hisse senedi fiyatlarındaki artışa gösterilecek tepkinin, varlık fiyatındaki yanlış hizalamaya veya baloncuğa verilecek uygun tepkiden çok farklı olacağını belirtmişlerdir. Merkez bankasının politika araçlarını aynı zamanda varlık fiyatlarını da gözeterek ayarlamasının ilk etapta varlık fiyatındaki yanlış hizalamaların ortaya çıkma olasılığını düşereceğini ileri sürmüşlerdir. Goodhart ve Hofmann (2000) tarafından yapılan çalışmanın sonuçlarına atıf yaparak, OECD ülkelerinin geniş bir örneğindeki enflasyonun, döviz kurundaki, konut fiyatlarındaki ve hisse senedi fiyatlarındaki değişikliklerden önemli ölçüde etkilendiğini, ABD pazarının daha büyük piyasa kapitalizasyonu ve hisse senetlerinin temsil ettiği hanehalkı servetinin daha büyük payı nedeniyle, hisse senedi fiyat değişikliklerinin ABD'de diğer OECD ülkelerine göre daha büyük bir etkisi olma eğiliminde olduğunu belirtmiş ve varlık fiyatlarının gelecekteki enflasyon üzerinde güçlü etkileri olabileceği kabulünü güçlendirmişlerdir. Cecchetti vd. (2002), enflasyon hedeflemesi yapan merkez bankalarının, hisse senedi fiyatındaki yanlış hizalamalara tepki vererek makroekonomik performansı iyileştirebileceğine inanmak için sağlam teorik nedenler olduğunu savunmuşlardır. Elde ettikleri tüm sonuçlar, hem çıktı açığının hem de hisse senedi fiyatının merkez bankasının kullandığı bilgilere dahil edilmesi gerektiğini göstermiştir. Bununla birlikte, merkez bankacılarının tüm varlık fiyatı değişikliklerine aynı şekilde tepki gösterdiği bir duruma karşı çıkmışlardır.

Filardo (2004), faiz oranının Taylor kuralı aracılı̆̆ıyla belirlendiği ve varlık fiyatı balonlarının patlama olasılığını etkilediği, böylece balonun içsel olarak faiz oranına bağıı olduğu basit Yeni Keynesyen bir modelde, merkez bankalarının genel olarak varlık fiyatı gelişmelerine ve özel olarak varlık fiyatı balonlarına sistematik olarak yanıt vermesi gerektiğine vurgu yapmıştır.

Proaktif politika duruşunu öneren diğer bir makalede, Goodhart ve Hofmann (2002), ekonominin tahmin edilen geriye dönük yapısal modeline dayanarak, reel faiz oranı ve reel döviz kurunun yanı sıra gayrimenkul ve hisse senedi fiyatlarının da G7 çıktı açıkları üzerinde önemli bir etkiye sahip olduğunu göstermişlerdir. Sunulan kanıtlar, para politikasının varlık fiyatı hareketlerine aktif bir şekilde yanıt vermesi gerektiği görüşünü desteklemektedir. Bununla birlikte, varlık fiyatlarına mekanik bir politika tepkisini savunmaktan ziyade, bu hareketlerin nedenlerinin kapsamlı bir analizinin yapılması ve varlık değerlemelerinin içselliğinin hesaba katılmasının önemine dikkat çekmişlerdir. Varlık fiyatlarının gelecekteki talep koşulları hakkında yararlı bilgiler içerdiğini ve varlık fiyatlarını göz ardı etmenin sadece bu bilgilerin kaybı anlamına gelmediğini, aynı zamanda para politikası analizinde kullanılan ampirik modellerde önemli yanlılığa yol açabileceğini göstermişlerdir.

Geleneksel görüş, düşük ve istikrarlı enflasyon olarak tanımlanan parasal istikrarın finansal istikrara katkıda bulunabileceğini ileri sürmektedir. Ancak bu görüş 2007 ve 2009 finans krizinden önce bile çokça eleştiri almış bir yaklaşımdır. Borio vd. (2003)'e göre, son on yıllık süreçte düşük enflasyon, daha olumlu enflasyon beklentilerinin ve para politikasının daha yüksek kredibilitesinin bir sonucudur. Bu da çıktı düzeyinde istikrarla birlikte, algılanan riskleri azaltır ve finansal piyasa katılımcılarını daha yüksek riskler almaya teşvik ederek varlık piyasalarında patlama-düşüş döngülerine neden olabilir. Bu nedenle, geleneksel görüşün aksine, düşük enflasyon ortamında ve enflasyon beklentilerinin daha iyi olduğu bir ortamda bile, finansal çalkantı olması beklenebilir. Borio vd. (2003) sözkonusu "kredibilite paradoksu"na rağmen merkez bankaları finansal istikrarı amaç fonksiyonlarına entegre etmeli mi sorusunu, yeni bir amaç değişkenin, diğer hedeflerden sapma olduğunda kamuoyu baskısı yaratabileceği endişesi ile kesin bir şekilde yanıtlamaktan 
kaçınmıştır. Gruen, Plumb ve Stone (2005), modellerinde optimum parasal tepkinin varlık balonunun stokastik özelliklerine bağıı olduğunu göstermişlerdir. Para politikasının gecikmeli yapısı nedeniyle proaktif politikanın, patlama sırasında parasal koşulların gevşemesiyle zaten ilişkili olabileceğini belirtmişlerdir. Dolayısıyla, varlık fiyat patlaması sırasında proaktif politikanın her zaman reaktif stratejiden daha gevşek bir politika gerektirdiği artık net değildir. Gruen vd. (2005), Kontonikas ve Montagnoli (2006), Ball (1999) ve Svensson (1997) modelinin bir uzantısını kullanarak politika yapıcıların varlık fiyatındaki yanlış hizalamalara yanıt vermesi gerektiğini göstermişlerdir (Raines vd., 2007).

Borio ve White (2004), Bordo ve Jeanne (2002) ve Roubini (2006) proaktif stratejilerin önemine vurgu yapmışlardır. Bu grup temsilcilerine göre, hisse senedi fiyatlarının genellikle kabarcıklara ve çökmelere maruz kalması güçlü konjonktür karşıtı etkilere sahip olabilir ve finansal piyasaların istikrarını da olumsuz yönde etkileyebilir. Reaktif strateji yaklaşımı merkez bankasının çıktı açığındaki oynaklığın azaltılmasına odaklanmasının hisse senedi fiyat balonlarını engelleyebileceğini ileri sürerken, proaktif strateji savunucuları merkez bankalarının finansal istikrardan sorumlu olduklarını, varlık fiyatlarını izlemeleri ve kabarcıkların ortaya çıkmasını önlemeye çalışmaları gerektiğini belirtmişlerdir. Bu görüşe göre, faiz oranının kullanılması kabarcıkların ortaya çıkmasını önlemede etkili olarak görülmektedir. Bununla birlikte, bu okuldan çok az iktisatçı, merkez bankasının hisse senedi fiyatının belirli bir değerini (enflasyon oranını hedeflediği gibi) hedeflemesi gerektiğini savunmaktadır. Bunun yerine birçoğu, "rüzgara karşı durma" stratejisinin hisse senedi fiyatlarındaki çok güçlü hareketleri azaltmak için yararlı olabileceğini iddia etmektedir. Faiz oranlarını manipüle ederek varlık fiyatlarının oynaklığını azaltmayı amaçlayan rüzgara karşı durma stratejileri, enflasyon hedeflemesi güvenilirliği olmadığında makroekonomik istikrarı artırmamaktadır (Grauwe, 2008).

Grauwe (2008), merkez bankaları, varlık fiyatlarını etkilemek ve balonların oluşmasını önlemek için faiz oranı araçlarını kullanmalı mı sorusunu davranışsal bir makroekonomik model kullanarak analiz etmiştir. Taylor kuralıyla güçlendirilmiş standart bir toplam talep toplam arz modelinde hisse senedi fiyatlarının toplam talep ve arzı etkilemesine izin vermiştir. Model, gelecekle ilgili inançların birbiriyle bağlantılı hale gelmesinden kaynaklanan patlama ve düşüşler üretmektedir. Elde edilen sonuçlar, merkez bankalarının hisse senedi fiyatlarını etkileyebileceğini ve borsada "rüzgara karşı durma" stratejilerini izleyerek, çıktı ve enflasyon arasındaki ödünleşimi iyileştirebileceklerini, yani hem üretim hem de enflasyondaki oynaklığı azaltabileceklerini göstermiştir. Ancak bu sonucun, yalnızca inandırıcı bir enflasyon hedeflemesi ortamında geçerli olduğunu belirtmiştir. Enflasyon hedefinin yüksek derecede güvenilirliği varsa, "rüzgara karşı durma" stratejilerinin makroekonomik istikrarı (çıktı ve enflasyon istikrarı) önemli ölçüde iyileştirdiğini ortaya koymuştur. Ancak, faiz oranlarını manipüle ederek varlık fiyatlarındaki oynaklığı azaltmayı amaçlayan bu politikaların, enflasyon hedeflemesinin kredibilitesi olmadığında makroekonomik istikrarı iyileştirmediğini göstermiştir.

Fuhrer ve Tootell (2008), hisse senedi fiyatları ve para politikası eylemleri arasındaki eşzamanlı etkileşimlerin yarattığı tanımlama sorununa yeni bir yaklaşım sunmuşlardır. Yaptıkları analiz, FOMC'nin, geleneksel FED hedef değişkenlerinin başarılı tahminleri için hisse senedi fiyatlarının sahip olduğu bilgilere yanıt vermesini ve FMOC'nin bu değişkenleri öngörmenin yanı sıra, hisse senedi fiyatlarındaki değişikliklere verdiği bağımsız yanıtı ayırt etmesini sağlamıştır. Çalışma, greenbook tahminleri ile ilgili bilgileri hisse senedi fiyat değişikliklerine etkin bir şekilde dahil etmektedir. Böylece, bu tahminlerin Taylor kurallarına dahil edilmesi, para politikası sürecinde hisse senedi fiyatlarının rolünü açıklığa kavuşturmaktadır. Çalışmada, FOMC'nin kabul edilen para politikası hedef değişkenlerinin bir tahmini yoluyla filtrelenmesi dışında FOMC'nin doğrudan hisse fiyatlarına yanıt vermesi yönündeki önermeyi destekleyen çok az kanıt bulmuşlardır.

Fukunaga ve Saito (2009), Bernanke, Gertler ve Gilchrist (1999)'in (BGG) modeline dayandırdıkları analizlerinde para politikası kuralına varlık fiyatlarını dahil etmiş ve varlık fiyatlarındaki hareketlerin ekonomideki verimsizliklerle ilişkilendirildiğinde Taylor kuralına varlık fiyatlarını dahil etmenin faydalı olabileceğini göstermişlerdir. Ancak, politika yapıcılar finansal çarpıklıklar ile varlık fiyatı hareketleri arasındaki ilişki hakkında sınırlı bilgiye sahip olduklarında faydalar azalmaktadır (Raines, Mcleod ve Leathers, 2007). 
Woodford (2011), fiyat ve üretim istikrarının yanında finansal istikrarın da merkez bankası açısından bir amaç olarak kabul edilmesinin, esnek enflasyon hedeflemesi kapsamında uygulanabilir olduğunu belirtmiştir. Bernanke (2011) gibi Mishkin (2011)'de, global finans krizinin ardından hem akademik hem de merkez bankaları nezdinde yapılan çalışmaların, finansal istikrarsızlıkları ekonomik modellerin kapsamına aldığını ve sözkonusu istikrarsızlıkların eklenmesiyle para politikası stratejisinin geliştirildiğini ortaya koyan yeni bir literatürün doğduğunu belirtmiştir. Agenor ve da Silva (2013) "bütünleşmiş enflasyon hedeflemesi" yaklaşımında finansal istikrarı merkez bankasının amaç fonksiyonuna dahil ederek para politikası ile makro ihtiyati politikayı ortak bir zeminde karakterize etmiştir. Borio ve Lowe'ün ileri sürdüğü "rüzgara karşı durma" stratejisine göre merkez bankasının ikincil bir amacı finansal istikrarı sağlamak olmalıdır. Yeterli uzunlukta bir zaman ufku tanımlanması halinde merkez bankasının faiz oranını enflasyon hedefi için gerekli olan orandan daha fazla miktarda arttırarak gelecek dönem ortaya çıkma olasıı̆ı̆ı olan bir finansal kriz ihtimalini bertaraf edebileceğini ortaya koymuştur. Cuaresma (2008), finansal dengesizliklerin daha da büyümesinin önüne geçilmemesi halinde öncelikle güçlü enflasyonist baskılarla birlikte aşırı ısınan ekonominin, balonların sönmesiyle birlikte resesyona gireceğini ve buna bağlı olarak enflasyonun hedeflenen oranın altında gerçekleşeceğini belirtmiştir. Bu nedenle ilk etapta proaktif strateji kapsamında uygulanan sıkı para politikasından dolayı oluşabilecek çıktı azalmaları takip eden aşamalarda ortaya çıkan patlama ve çöküntülerin yıkıcı etkilerine karşı bir 'sigorta primi' olarak addedilmelidir (Doğan ve Akbakay, 2016).

Bulut (2017), TCMB'nin tepki fonksiyonunu varlık fiyatlarıyla genişletmiş ve 2009-2015 dönemine ait verileri kullanarak TCMB'nin varlık fiyatlarına tepki verip vermediğini incelemiştir. Ampirik analizin sonuçlarına göre, gecelik faiz oranları enflasyon beklentisi ile enflasyon hedefi arasındaki farkla ve döviz kuru açığıyla pozitif ve çıktı açığıyla negatif ilişkiliyken, borsa endeksi açığının katsayısı anlamsızdır. Tursoy (2019), Türkiye'de 2001 M1 - 2017M4 dönemi için ARDL Sınır testi ve Johansen Eşütünleşme testi kullanarak, hisse senedi fiyatı ile faiz oranları arasında anlamlı ve uzun vadeli bir ilişki olduğunu göstermiştir. Faiz oranlarının hisse senedi fiyatları üzerinde negatif bir etkisinin olduğunu ve bunun beklenen nakit akışı hipotezi ile tutarlı olduğunu belirtmiştir. Çalışma aynı zamanda hisse senedi fiyatlarının da faiz oranları üzerinde negatif yönde bir etkisinin olduğunu göstermiştir.

\section{Veri Seti ve Yöntem}

Çalışma kapsamında, seçili OECD ülkelerinde ${ }^{1}$, 2000-2019 yılları için, hisse fiyatları, enflasyon açığı ve çıktı açığının kısa vadeli faiz oranı üzerindeki etkisi analiz edilmiştir. Ülkeler gelişmiş ve gelişmekte olan ülkeler olmak üzere iki gruba ayrılmış, Çekya, Polonya, Slovakya, Meksika, Kore, Letonya gelişmekte olan ülkeler kategorisinde değerlendirilirken diğer ülkeler gelişmiş ülkeler kategorisinde ele alınmıştır. Çalışma kapsamında analiz edilen değişkenler kısa vadeli faiz oranı (KVFaiz), enflasyon açığı (gerçekleşen enflasyonenflasyon tahmini) (ENFaçı̆̆ı), çıktı açığını temsilen işsizlik oranı ve hisse fiyatlarıdır (HisseFiyatları). Veriler, para politikası reaksiyon fonksiyonunda geliştirilmiş Taylor kuralı kapsamında hisse senedi fiyatlarına yerveren Fuhrer ve Tootell (2008)'in çalışmasını temel alarak belirlenmiştir. Yıllık olarak alınan veriler OECD ve World Development Indicators veri tabanlarından elde edilmiştir.

Hisse senedi fiyatlarının kısa vadeli faiz oranları üzerindeki etkisinin incelendiği çalışmada iki temel model kullanılmıştır.

$$
\begin{aligned}
& \text { KVFaiz }_{i, t}=\beta_{0}+\beta_{1} * \text { KVFaiz }_{i, t-1}+\beta_{2} * \text { HSenedi }_{i, t}+\beta_{3} * E n f A c ̧ ı \breve{g}_{i, t}+\beta_{4} * \text { ÇıtıtıAçı̆ } l_{i, t}+\beta_{5} * \\
& \text { EnfAçı̆̆ } l_{i, t}+\beta_{6} * \text { Geliş̧mekte }+\beta_{7} * \text { Gelişmekte } * \text { HSenedi } i_{i, t}+u_{i, t}
\end{aligned}
$$

Model 1'de;

KVFaiz $_{i, t}$; kısa vadeli faiz oranı; piyasada kısa vadeli devlet kâğıtlarının ihraç veya işlem gördüğü üç aylık para piyasası faiz oranı,

$H S e n e d i_{i, t}$ aylık veriler için kapanış günlük değerleri kullanılarak borsa tarafından belirlenen günlük verilerin ortalamalarından oluşturulan hisse senedi fiyat endeksi, 
ÇılktıAçı̆̆ ; işsizlik oranı,

$E n f A c ̧ \iota \breve{g} l_{i, t} ;$ tüketici fiyat endeksi (TÜFE) ile ölçülen enflasyon oranı ile enflasyon beklentisi arasındaki farktır.

Modele aynı zamanda gelişmekte olan ülkeler için 1 değeri, diğer ülkeler için 0 değeri alan gelişmekte olan ülkeler kukla değişkeni eklenmiştir. Hisse senedi fiyatlarının kısa vadeli faiz oranı üzerindeki etkisinin analizinde, gelişmiş ve gelişmekte olan ülkeler ayrımını yapmak maksadıyla gelişmekte olan ülkeler için oluşturulan kukla değişkeni ile hisse senedi endeksi değişkeni arasında etkileşim terimi oluşturulup modele eklenmiştir. Hem elde edilen sonuçların sağlamlığının testi hem de piyasa kapitalizasyonunun hisse senedinin kısa vadeli faiz oranı üzerindeki etkisi üzerinde belirleyici olabileceği beklentisi nedeniyle aşağıda gösterilen ikinci model çalıştırılmıştır.

$K V F a i z_{i, t}=\beta_{0}+\beta_{1} * K V F a i z_{i, t-1}+\beta_{2} * H S e n e d i_{i, t}+\beta_{3} * E n f A c ̧ ı \breve{g} l_{i, t}+\beta_{4} *$ ÇıtıtıAçı̆̆ $l_{i, t}+\beta_{5} *$ EnfAçı̆̆ $\iota_{i, t}+\beta_{6} *$ Gelişmekte $+\beta_{7} *$ PiyasaKap $+\beta_{7} *$ PiyasaKap $*$ HSenedi $i_{i, t}+u_{i, t}$

Model 2'de;

PiyasaKap; borsada işlem gören yerli şirketlerin piyasa değerinin GSYiH'nin yüzdesi olarak ifadesidir.

Çalışmada statik model yerine dinamik panel veri analizi yöntemi seçilmiştir. Dinamik panel veri modellerinde, bağımlı değişkenin gecikmeli değerleri açıklayıcı faktörler arasında yer almaktadır (Tatoğlu, 2013).

Bağımlı değişkenin gecikmeli değerinin açıklayıc faktörler arasında yer alması modelin katsayılarının yansızlığını tehdit eden birtakım sıkıntılara neden olabilmektedir. Greene'in (2000) gösterdiği üzere gecikmeli bağımlı değişkenin hata terimleri ile ilişkili olması durumu söz konusudur. Bu durumda dinamik panel veri analizinde geleneksel panel veri metodlarının kullanılması tutarsız sonuçların elde edilmesine neden olabilecektir. Bu duruma getirilen çözümlerden ilki Anderson ve Hsiao (1981) tarafından önerilmiştir. Bu metod aşağıdaki şekilde gösterilebilir.

$$
\Delta y_{i, t}=\emptyset \Delta y_{i, t-1}+\Delta x_{, i, t-1}+\Delta u_{, i, t-1}
$$

Anderson ve Hsiao (1981) tarafından önerilen yöntemde ilk olarak değişkenlerin farkları alınarak hata teriminde yer alan birim etkisi elimine edilmiştir. Ancak hata terimlerinden birim etkisi çıkarılmasına rağmen $\Delta y_{i, t-1}$ ile $\Delta u, i, t-1$ arasında korelasyon vardır. Bu durum, regresyon katsayılarının yansızlığını tehdit etmektedir. Anderson Hsiao buna karşın $\Delta y_{i, t-2}$ veya $y_{i, t-2}$ 'nin araç değişken olarak kullanılmasını önermiştir. Ancak bu yönteme ilişkin ortaya çıkan problemler, ekonometrik analizlerde söz konusu yöntemin kullanımını sınırlandırmıştır.

İlk olarak Arellano ve Bond (1981) bu modelin asimptotik olarak etkin olmadığını göstermiştir. Daha sonra Kruiniger (2008) ve Phillips (2015) $\varnothing=1$ hipotezinin reddedilemediği durumda, zamanın sabit bir dönemi kapsaması durumunda bile tutarsız olduğunu, $T \rightarrow \infty$ durumunda ise tutarlı, ancak etkin olmadığını göstermiştir. Son olarak, Arellano ve Bover (1995), $\varnothing 1^{\prime} e$ yaklaştıkça katsayıların varyanslarının çok yükseleceğini, bu etkinin $\emptyset^{\prime}$ nın $0,80^{\prime}$ e eşit olması durumunda dahi ortaya çıkacağını göstermiştir. Sözkonusu problemler, Anderson ve Hsiao (1981) yönteminin ekonometrik analizlerde kullanımını oldukça sınırlamıştır. Bu sebeplerle dinamik panel veri analizini içeren bu çalışmada, sözkonusu yönteme yer verilmemiştir.

Arellano ve Bond (1991), Anderson ve Hsiao yönteminin etkinsizliğinin araç değişken olarak sadece $\Delta y_{i, t-2}$ veya $y_{i, t-2}$ 'yi kullanmasından kaynaklandığını, gerçekte araç değişken olarak olası tüm araç değişkenlerin kullanılabileceğini belirtmişlerdir. Kendi geliştirdikleri yöntemde, olası tüm geçerli gecikmeli değişkenlerin dinamik panel veri modellerinde araç değişken olarak kullanılmasını önermiş, bu bağlamda genelleştirilmiş momentler yöntemini (GMM) geliştirmiş̧erdir. Arellano ve Bover (1995), Sistem-GMM tahmincisi ile modele katkıda bulunmuşlardır. Blundell ve Bond (1998) Sistem-GMM yöntemini geliştirmiş ve birinci fark GMM tahmincisinin $\emptyset^{\prime}$ nın $0,80^{\prime}$ e eşit olduğu durumda dahi katsayıları anlamlı şekilde düşük tahmin ettiğini ortaya koymuş, Sistem-GMM yönteminin daha iyi sonuçlar sunduğunu göstermiştir. 
Sistem GMM yönteminde hem fark denklemi hem de düzey denklemi kullanılırken, fark denkleminde bağımlı değişkenin gecikmeli fark değeri $\left(\Delta y_{i, t-1}\right)$ için düzey değişken $y_{i, t-2}$ araç değişken olarak kullanılırken, düzey denklemde kullanılan $y_{i, t-1}$ için fark değişken $\left(\Delta y_{i, t-2}\right)$.araç değiken olarak kullanılmıştır. Bu yöntemin sadece içsellik sorunu değil birim içindeki otokorelasyon ve değişen varyans problemini de çözebiliyor olması, modeli yoğun olarak tercih edilen bir yöntem haline getirmektedir (Akay, 2015). Bahsedilen nedenler ışığında, bu çalışma kapsamında Sistem-GMM yöntemi kullanılmaktadır.

\section{Tahmin Sonuçları}

Hisse senedi fiyat endeksinin kısa vadeli faiz oranı üzerindeki etkisi Sistem GMM metoduyla test edilmiş, elde edilen sonuçlara Tablo 1'te yer verilmiştir.

Tablo 1. Kısa Vadeli Faiz Oranı Üzerinde Hisse Senedi Fiyatlarının Etkisi

\begin{tabular}{|c|c|c|}
\hline \multirow[t]{2}{*}{ Bağımlı Değişken } & \multicolumn{2}{|c|}{ Kısa Vadeli Faiz Oranı } \\
\hline & (1) & (2) \\
\hline \multirow[t]{2}{*}{ Kısa Vadeli Faiz Oranı t-1 } & $0,348 * * *$ & $0,7576^{* * *}$ \\
\hline & $(0,087)$ & $(0,0915)$ \\
\hline \multirow[t]{2}{*}{ Kısa Vadeli Faiz Oranı t-2 } & & $-0,175 * * *$ \\
\hline & & $(0,057)$ \\
\hline \multirow[t]{2}{*}{$\log ($ Hisse Senedi Endeksi) t } & $0,374^{*}$ & 0,11 \\
\hline & $(0,193)$ & $(0,16)$ \\
\hline \multirow[t]{2}{*}{ Enflasyon Açı̆̆ı t } & $0,87 * *$ & $0,2^{*}$ \\
\hline & $(0,39)$ & $(0,1)$ \\
\hline \multirow[t]{2}{*}{ Çıktı Açığı t } & $-0,70^{* * *}$ & $-0,03 * *$ \\
\hline & $(0,23)$ & $(0,015)$ \\
\hline \multirow[t]{2}{*}{ Gelişmekte Olan Ülkeler } & $2,85^{* * *}$ & $0,90 * *$ \\
\hline & $(0,54)$ & $(0,44)$ \\
\hline \multirow[t]{2}{*}{ Gelişmekte* $\log ($ Hisse Senedi) } & $-0,021 * * *$ & \\
\hline & $(0,005)$ & \\
\hline \multirow[t]{2}{*}{ Piyasa Kapitalizasyonu } & & $-0,032^{* *}$ \\
\hline & & $(0,014)$ \\
\hline \multirow[t]{2}{*}{ Piyasa Kapitalizasyonu*Iog(Hisse Senedi Endeksi) } & & $0,01^{* *}$ \\
\hline & & $(0,003)$ \\
\hline$B 2=B 7=0 p$-değeri & 0,000 & 0,08 \\
\hline Yıl Etkisi Kontrolü & Evet & Evet \\
\hline$A R(1)$ test istatistiği & 0,000 & 0,03 \\
\hline AR(2) Test P-değeri & 0,83 & 0,09 \\
\hline Sargan Test p-değeri & 0,40 & 0,16 \\
\hline Gözlem Sayısı & 570 & 339 \\
\hline Wald Test p-değeri & 0,000 & 0,000 \\
\hline
\end{tabular}

$*, * *, * * *$ katsayıları sırasıyla $\% 10, \% 5$ ve \%1 düzeylerinde anlamlılıklarını göstermektedir. Parantez içerisinde yer alan değerler, katsayılara ilişkin standart hataları vermektedir. Hisse senedi değişkeni, etkileşim terimleri ile beraber modele konulduğundan, hisse senetleri ile etkileşim terimlerinin anlamlılıkları beraberce de test edilmiş, bu test sonucuna ilişkin $p$-değeri tabloda rapor edilmiştir. 
Regresyon sonuçlarının yer aldığı Tablo 1'te görüldüğü üzere her iki modelde de sabit zaman etkisi kontrol edilmiştir. Wald testi sonuçlarına göre, her iki modelin de anlamlı olduğu görülmektedir. Wald test sonuçlarına ilişkin p-değeri 0,000 ile \%1 düzeyinin dahi altında kalmış, bu da modelin anlamsız olduğunu savunan sıfır hipotezinin reddedilmesi gerektiğini göstermektedir. Bunun yanında Sargan testi ile araç değişkenlerin dışsalıkları test edilmiş, Sargan testi sonucuna ilişkin olasılık değerinin her iki modelde de \%5 anlamlıık düzeyinin üstünde çıkması modellerde kullanılan araç değişkenlerin dışsal olduklarını savunan sıfır hipotezinin reddedilmemesi gerektiğini göstermektedir. Bunlara ek olarak, her iki model için regresyonların hata terimlerinin 1. dereceden ve 2 . dereceden otokorelasyon varlığı sınanmış ve istenildiği gibi $A R(1)$ test istatistiği anlamlı çıkarken; AR(2) test istatistiği ise anlamsız olduğu sonucuna ulaşıımıştır. System-GMM modellerinin geçerliliğine ilişkin yapılan test sonuçları, modellerin geçerli ve yansız olduğunu göstermektedir.

Model 1'de kısa vadeli faiz oranının birinci gecikme uzunluğu modele eklenmiştir. Birinci gecikme uzunluğuna ilişkin katsayının \%1 düzeyinde dahi anlamlı olması kısa vadeli faiz oranlarındaki değişimin açıklanmasında dinamik panel veri analizinin uygun yöntem olduğuna işaret etmektedir. Model 1 sonuçlarına göre, enflasyon açığı, çıktı açığı kontrol edildikten sonra hisse senedi fiyatları kısa vadeli faiz oranları üzerinde \%10 düzeyinde anlamlı etkiye sahiptir. Diğer yandan, hisse senedi fiyat endeksi ile gelişmekte olan ülkeler kukla değişkeni arasında oluşturulan etkileşim terimi de modelde yer almaktadır. Hisse senedinin kısa vadeli faiz oranı üzerindeki etkisini belirlemek için bu iki değişkenin anlamlılığına ilişkin $\beta_{2}=\beta_{7=0}$ hipotezi birlikte test edildiğinde $p$-değeri \%1 düzeyinin dahi altında çıkmıştır. Bu durum hisse senedinin kısa vadeli faiz oranı üzerinde etkili olduğunu göstermektedir. Diğer yandan regresyon sonuçları, hisse senedinin kısa vadeli faiz oranı üzerindeki etkisi gelişmekte olan ülkeler ile gelişmiş ülkeler arasında anlamlı şekilde farklılık gösterdiğini önermektedir. Regresyon sonuçlarına göre gelişmiş ülkelerde hisse senedi endeksindeki \%1'lik artış kısa vadeli faiz oranını ortalama 0,037 puan arttıırken bu etki gelişmekte olan ülkelerde 0,035 puan olarak gerçekleşmekte ve bu farklılık \%1 düzeyinde dahi anlamlı çıkmaktadır.

Diğer yandan, Model 1 sonuçları gelişmekte olan ülkelerde kısa vadeli faiz oranının gelişmiş ülkelerin kısa vadeli faiz oranının ortalama 2,85 puan üzerinde olduğunu göstermektedir. Gelişmekte olan ülkeler ile gelişmiş ülkeler arasındaki kısa vadeli faiz oranı açısından söz konusu farklıılı yine \%1 düzeyinde dahi anlamlıdır.

Model 1 sonuçları enflasyon açığı ile kısa vadeli faiz oranları arasında yine ekonomik teoriye uygun bir ilişki tespit etmiştir. Elde edilen bulgulara göre, enflasyon açığındaki 1 puanlık artış kısa vadeli faiz oranının ortalama 0,87 puan artmasına neden olmaktadır. Bu etki de \%5 düzeyinde anlamlıdır. Çıktı açığını ölçmek için kullanılan işsizlik oranı ile kısa vadeli faiz oranı arasında beklendiği üzere negatif bir ilişki bulunmuştur. Regresyon sonuçlarına göre işsizlik oranındaki bir puanlık artış, kısa vadeli faiz oranını \%1 düzeyinde dahi anlamlı şekilde ortalama 0,70 puan düşürmektedir.

Model 2 ile hem Model 1 sonuçlarının sağlamlığı test edilmiş hem de kısa vadeli faiz oranı hisse senetleri arasındaki ilişkinin incelenmesinde piyasa kapitalizasyonunun etkisi kontrol edilmiştir. Model 2'ye piyasa kapitalizasyonu değişkeninin yanında piyasa kapitalizasyonu ile hisse senedi arasında oluşturulan etkileşim terimi de eklenmiştir. Bu yöntemle, hisse senedinin kısa vadeli faiz oranı üzerindeki olası etkisinin piyasa kapitalizasyonundan etkilenip etkilenmediği de test edilebilecektir. Elde edilen bulgulara göre, hisse senedi fiyat endeksinin kısa vadeli faiz oranı üzerinde anlamlı etkisi olmadığı görülmektedir. Ancak hisse senedi fiyat endeksi ile piyasa kapitalizasyonu etkileşim terimine ilişkin olasılık değeri \%5 düzeyinde anlamlı çıkmışır. Etkileşim teriminin katsayısının pozitif çıkması hisse senedi endeksinin kısa vadeli faiz oranı üzerindeki etkisinin piyasa kapitalizasyonu arttıkça arttığını göstermektedir. Diğer bir deyişle, şirketlerin hisselerinin piyasa değeri arttıkça kısa vadeli faiz oranı hisse senedi fiyat değişimlerine daha fazla tepki vermektedir. Bu bulgular Model 1 sonuçlarını da bir açıdan doğrulamaktadır. Model 2 de, Model 1 gibi piyasa kapitalizasyonunun yüksek olduğu gelişmiş ülkelerde hisse senedi fiyatlarının kısa vadeli faiz oranı üzerindeki etkisinin piyasa kapitalizasyonunun göreceli düşük olduğu gelişmekte olan ülkelerde hisse senedi fiyatlarının kısa vadeli faiz oranı üzerindeki etkisinden yüksek olduğunu önermektedir.

Model 2 regresyonu sonucu elde edilen diğer bulgularda Model 1'in bulgularını doğrulamaktadır. Enflasyon açı̆̆ının faiz oranı üzerindeki etkisi pozitif ve \%10 düzeyinde anlamlı iken, işsizlik ile kısa vadeli faiz 
oranı arasındaki ilişki Model 1'in önerdiği gibi negatif ve \%5 düzeyinde anlamlıdır. Model 2'ye göre de gelişmekte olan ülkelerin kısa vadeli faiz oranları gelişmişülkelerin kısa vadeli faiz oranlarından anlamlı şekilde yüksektir. Model 1'de yer almayan piyasa kapitalizasyonu değişkeninin kısa vadeli faiz oranı üzerindeki etkisi de beklenti yönünde negatif ve anlamlıdır.

\section{Sonuçlar}

Bu çalışmada, seçili OECD ülkelerinde 2000-2019 yılları için, hisse fiyatları, enflasyon açığı ve çıktı açığının kısa vadeli faiz oranı üzerindeki etkisi, Sistem GMM yöntemi kullanılarak analiz edilmiştir. Çalışmada iki temel model kullanılmıştır. Gelişmekte olan ülkeler kukla değişkeni ve geliş̧mekte olan ülkeler kukla değişkeni ile hisse senedi endeksi değişkeni arasında oluşturulan etkileşim teriminin eklenmesiyle elde edilen birinci model, hisse senedinin kısa vadeli faiz oranı üzerinde etkili olduğunu göstermektedir. Bununla birlikte, hisse senedi fiyat endeksinin kısa vadeli faiz oranı üzerindeki etkisi gelişmekte olan ülkeler ile gelişmiş ülkeler arasında anlamlı şekilde farklııı göstermektedir. Bu durum merkez bankalarının faiz politikalarının gelişmiş ülkelerde hisse senedi fiyatlarına daha duyarlı olduğunu göstermektedir.

Birinci modelden elde edilen diğer bir sonuç, gelişmekte olan ülkelerde kısa vadeli faiz oranının gelişmiş ülkelerin kısa vadeli faiz oranının üzerinde olduğunu ortaya koymaktadır. Gelişmekte olan ülkelerin gelişmiş ülkelere nazaran ekonomik risklere karşı daha kırılgan olması bu ülkelerin risk primini arttırmakta, bu durum kendisini, kısa vadeli faiz oranlarının gelişmiş ülkelere göre daha yüksek olması şeklinde göstermektedir. Dolayısıyla sözkonusu bulguların ekonomik teori ve pratiği ile oldukça uyumlu olduğu söylenebilir.

Birinci modelden elde edilen sonuçlar ayrıca, enflasyon açığı ile kısa vadeli faiz oranları arasında yine beklendiği üzere pozitif bir ilişki saptanmıştır. Enflasyon açığı arttıkça kısa vadeli faiz oranları artış yönünde cevap vermektedir. Çıktı açığını ölçmek için kullanılan işsizlik oranı ile kısa vadeli faiz oranı arasında ise negatif bir ilişki ortaya konmuştur. Nitekim, işsizlik oranının artmasının merkez bankalarına faiz oranlarını düşürme yönünde baskı yapması beklenir.

Piyasa kapitalizasyonu değişkeninin yanında piyasa kapitalizasyonu ile hisse senedi arasında oluşturulan etkileşim teriminin eklendiği ikinci modelden elde edilen sonuçlara göre ise, hisse senedi fiyat endeksinin kısa vadeli faiz oranı üzerinde anlamlı bir etkisi bulunmamaktadır. Diğer taraftan hisse senedi fiyat endeksi ile piyasa kapitalizasyonu etkileşim terimine ilişkin olasılık değeri anlamlıdır. Etkileşim teriminin pozitif katsayısı, hisse senedi fiyat endeksinin kısa vadeli faiz oranı üzerindeki etkisinin piyasa kapitalizasyonu arttıkça arttığını ortaya koymaktadır. Bu kapsamda, borsaya kayıtı şirketlerin hisselerinin piyasa değerinin GSYiH içerisindeki payı arttıkça kısa vadeli faiz oranının hisse senedi fiyat değişimlerine daha fazla tepki verdiği söylenebilir. Modelde, piyasa kapitalizasyonunun kısa vadeli faiz oranı üzerindeki etkisi ise negatif ve anlamlıdır. Hisse senetleri şirketler için borçlanma gibi finans kaynaklarından biridir. Piyasa kapitalizasyonunun yükselmesinin şirketlerin sermaye yoluyla finanse edilmesini daha cazip hale getirmesi, bu durumun piyasa borçlanma talebini düşürmesi beklenmektedir. Dolayısıyla piyasa kapitalizasyonu arttıkça, faiz oranlarının düşmesi beklenen bir durumdur.

Nihai olarak gerek birinci model gerekse ikinci model bulguları, hisse senedi fiyatının merkez bankalarının kısa vadeli faiz oranını belirlemeleri sürecinde anlamlı etkisi olduğunu doğrulamaktadır. Bu etkinin gelişmiş ülkelerde gelişmekte olan ülkelere nazaran daha yüksek olduğu tespit edilmiştir. İkinci modelde piyasa kapitalizasyonunun denkleme eklenmesi, hisse senedinin kısa vadeli faiz oranı üzerindeki etkisinin piyasa kapitalizasyonu arttıkça arttığını göstermiştir. Dolayısıyla, gelişmiş ülkelerde hisse senedi fiyatının kısa vadeli faiz oranı üzerindeki etkisinin daha yüksek olması bu ülkelerde piyasa kapitalizasyonu oranının daha yüksek olmasıyla da açıklanabilir. 


\section{Beyan ve Açıklamalar (Disclosure Statements)}

1. Bu çalışmanın yazarı, araştırma ve yayın etiği ilkelerine uyduğunu kabul etmektedir (The author of this article confirms that her work complies with the principles of research and publication ethics).

2. Yazar tarafından herhangi bir çıkar çatışması beyan edilmemiştir (No potential conflict of interest was reported by the author).

3. Bu çalışma, intihal tarama programı kullanılarak intihal taramasından geçirilmiștir (This article was screened for potential plagiarism using a plagiarism screening program).

\section{Son Notlar}

1. Avusturya, Avustralya, Belçika, Kanada, isviçre, Çekya, Almanya, Danimarka, ispanya, Estonya, Finlandiya, Fransa, Ingiltere, Yunanistan, İzlanda, İsrail, Italya, Kore, Lüksemburg, Letonya, Meksika, Hollanda, Norveç, Yeni Zelanda, Polonya, Portekiz, Slovakya, Isveç ve ABD.

\section{Kaynaklar}

Akay, Ç. (2015). Dinamik panel veri modelleri, Stata ile panel veri modelleri. İstanbul: Der Yayınları.

Bernanke, B. S., \& Gertler, M. (2001). Should central banks respond to movements in asset prices? American Economic Review, 91(2), 253-257.

Bernanke, B., \& Gertler, M. (1999). Monetary policy and asset volatility. Economic Review, Federal Reserve Bank of Kansas City, 84(QIV), 17-51.

Bordo, M. D., \& Jeanne, O. (2002). Monetary policy and asset prices: Does 'benign neglect' make sense? International Finance, 5(2), 139-164.

Borio, C., \& White, W. (2004). Whither monetary and financial stability? The implications of evolving policy regimes. Basel: BIS.

Bulut, Ü. (2017). Küresel krizi izleyen dönemde para politikası ve varlık fiyatları: Türkiye örneği. Eskişehir Osmangazi Üniversitesi IiBF Dergisi, 12(1), 13-30.

Cecchetti, S. G., Genberg, H., \& Wadhwani, S. (2002). Asset prices in a flexible Inflation targeting framework. Cambridge: NBER Working Paper Series.

Cecchetti, S. G., Genberg, H., Lipsky, J., \& Wadhwani, S. (2000). Asset prices and central bank policy. Geneva: ICMB and the CEPR.

Chami, R., Cosimano, T. F., \& Fullenskamp, C. (1999). The stock market channel of monetary policy. IMF.

Clarida, R., Gali, J., \& Gertler, M. (1998). Monetary policy rules in practice: Some international evidence. European Economic Review, 42(6), 1033-1067.

Clarida, R., Gali, J., \& Gertler, M. (1999). The science of monetary policy: A New Keynesian perspective. Journal of Economic Literature, 37(4), 1661-1707.

Clarida, R., Gali, J., \& Gertler, M. (2000). Monetary policy rules and macroeconomic stability: Evidence and some Theory. The Quarterly Journal of Economics, 115(1), 147-180.

Davis, E. P. (2010). New international evidence on asset price effects on investment and a survey for consumption. OECD Journal: Economic Studies.

Doğan, B. B., \& Akbakay, Z. (2016). Enflasyon hedeflemesi stratejisi: Küresel finansal krizin öğrettikleri. Bingöl Üniversitesi Sosyal Bilimler Enstitüsü Dergisi, 6(12),73-96.

Fernandez, A. Z., \& Nikolsko-Rzhevskyy, A. (2007). Measuring the Taylor rule's performance. Economic Letter, 2(6), 1-8.

Filardo, A. (2004). Monetary policy and asset price bubbles: Calibrating the monetary policy trade-offs. Basel: Bank for International Settlements.

Fuhrer, J., \& Tootell, G. (2008). Eyes on the prize: How did the fed respond to the stock market. Journal of Monetary Economics, 55(4), 796-805.

Geske, R., \& Roll, R. (1983). The fiscal and monetary linkage between stock returns and inflation. The Journal of Finance, $38(1), 1-34$. 
Goodhart, C., \& Hofmann, B. (2002). Asset prices and the conduct of monetary policy. Royal Economic Society Annual Conference.

Grauwe, P. D. (2008). Stock prices and monetary policy. CEPS Working Document No. 304.

Greenspan, A. (1996). The challenge of central banking in a democratic society. FED, Washington, D.C.

Greenspan, A. (2004). Risk and uncertainty in monetary policy. San Diego, California: American Economic Association.

Greenspan, A. (2007). The age of turbulence: Adventures in a new world. London: Penguin Books.

Kent, C., \& Lowe, P. (1997). Asset-price bubbles and monetary policy. Economic Research Department, Reserve Bank of Australia.

Knütter, R., \& Wagner, H. (2012). Monetary policy and boom-bust cycles in asset prices: A literature survey. (Ed.) P. E. Schulz \& B. P. Hoffmann, Financial asset pricing: Theory, global policy and dynamics. Nova Publishers.

Koenig, E. F. (2004). Optimal monetary policy in economies with sticky-information wages. Federal Reserve Bank of Dallas.

Murray, C., Nikolsko-Rzhevskyy, A., \& Papell, D. (2008). Inflation persistence and the Taylor principle. Munich Personal RePEc Archive (11353).

Posen, A. S. (2006). Why central banks should not burst bubbles. Washington, DC: Institute for International Economics.

Raines, J. P., Mcleod, J. A., \& Leathers, C. G. (2007). Theories of stock prices and the Greenspan-Bernanke doctrine on stock market bubbles. Journal of Post Keynesian Economics, 29(3), 393-408.

Reinhart, V. R. (2005). Equity prices and monetary policy in the United States (ss. 280-300). BIS.

Roubini, N. (2006). Why central banks should burst bubbles. International Finance, 9(1), 87-107.

Schwartz, A. J. (2002). Asset price inflation and monetary policy. NBER Working Paper.

Smets, F. (1997). Financial-asset prices and monetary policy: Theory and evidence. BIS Working Papers.

Svensson, L. E. (2004). Asset prices and ECB monetary policy. CEPR and NBER.

TCMB, (2013). Parasal aktarım mekanizması. Ankara: TCMB.

Tursoy, T. (2019). The interaction between stock prices and interest rates in Turkey: Empirical evidence from ARDL bounds test cointegration. Financial Innovation, 5(7), 1-12.

Vasilenko, A. (2017). Should monetary authorities prick asset price bubbles? Evidence from a new Keynesian model with an agent-based financial market. National Research University Higher School of Economics. 


\section{Ekler}

\section{Ek 1.}

Birinci mertebeden AR (1) için Arellano-Bond testi: $z=-8,98 \operatorname{Pr}>z=0,000$

Birinci mertebeden AR (2) için Arellano-Bond testi: $z=0,27 \operatorname{Pr}>z=0,791$

Sargan testi aşırı tanımlama kısıtları: chi2(420) $=454,65$ Prob $>$ chi2 $=0,11$ 